\section{What's in a Name? The Importance of Students Perceiving That an Instructor Knows Their Names in a High-Enrollment Biology Classroom}

Katelyn M. Cooper, ${ }^{\dagger}$ Brian Haney, ${ }^{\dagger}$ Anna Krieg, and Sara E. Brownell*

Biology Education Research Lab, School of Life Sciences, Arizona State University,

Tempe, AZ 85281

\begin{abstract}
Learning student names has been promoted as an inclusive classroom practice, but it is unknown whether students value having their names known by an instructor. We explored this question in the context of a high-enrollment active-learning undergraduate biology course. Using surveys and semistructured interviews, we investigated whether students perceived that instructors know their names, the importance of instructors knowing their names, and how instructors learned their names. We found that, while only $20 \%$ of students perceived their names were known in previous high-enrollment biology classes, $\mathbf{7 8 \%}$ of students perceived that an instructor of this course knew their names. However, instructors only knew $53 \%$ of names, indicating that instructors do not have to know student names in order for students to perceive that their names are known. Using grounded theory, we identified nine reasons why students feel that having their names known is important. When we asked students how they perceived instructors learned their names, the most common response was instructor use of name tents during in-class discussion. These findings suggest that students can benefit from perceiving that instructors know their names and name tents could be a relatively easy way for students to think that instructors know their names.
\end{abstract}

\section{INTRODUCTION}

Learning student names is generally promoted as a good teaching practice (Gorham, 1988; Page, 2004; Zakrajsek, 2007; Tanner, 2011, 2013; Chambliss, 2014), yet the research literature on this practice is relatively sparse. Most of these recommendations take the form of teaching tips that often summarize anecdotes or report from a general faculty perspective that learning names is important, because it can build studentinstructor relationships (Tanner, 2011), help create a positive classroom atmosphere (Tanner, 2013), and serve as an indicator that an instructor cares (Tanner, 2011). However, we know of no research literature that actually links student perception of their names being known to affective student outcomes.

The limited published data on the benefits of knowing student names are typically situated within the literature on instructor immediacy. Instructor immediacy is the perception of physical and psychological closeness between students and an instructor (Mehrabian, 1971). Immediacy behaviors can be nonverbal (e.g., smiling, gesturing while talking, appropriate touching; Richmond, 1987) or verbal (e.g., using terms like "we" to describe the class, giving students feedback, allowing students to call the instructor by his or her first name; O'Sullivan et al., 2004). Instructor immediacy has generally been positively correlated with perceived instructor responsiveness (Thomas et al., 1994), perceived instructor caring (Thweatt, 1999), and positive student evaluations (Moore et al., 1996). Moreover, instructor immediacy appears to impact students themselves: instructor immediacy has been positively correlated with student
Nancy Pelaez, Monitoring Editor Submitted August 31, 2016; Revised November 7 , 2016; Accepted November 29, 2016

CBE Life Sci Educ March 1, 2017 16:ar8 DOI:10.1187/cbe.16-08-0265

'These authors contributed equally to this work. *Address correspondence to: Sara E. Brownell (sara.brownell(aasu.edu).

(C) 2017 K. M. Cooper, B. Haney, et al. CBE-Life Sciences Education @ 2017 The American Society for Cell Biology. This article is distributed by The American Society for Cell Biology under license from the author(s). It is available to the public under an Attribution-Noncommercial-Share Alike 3.0 Unported Creative Commons License (http://creativecommons.org/licenses/ by-nc-sa/3.0).

"ASCB®" and "The American Society for Cell Biology $\circledast "$ are registered trademarks of The American Society for Cell Biology. 
participation (Christensen et al., 1995; Menzel and Carrell, 1999; Rocca, 2004), student affect (Gorham, 1988), and even student learning (Kelley and Gorham, 1988; Christophel, 1990; Chesebro and McCroskey, 2001; Titsworth, 2001).

While instructor immediacy has been shown to improve student experiences in traditional lecture, we know very little about how instructor immediacy influences students in active-learning classrooms. In contrast to traditional lecture, students in active-learning classrooms are expected to interact more frequently with one another as well as with the instructor (Eddy, Brownell, et al., 2014, 2015; Seidel et al., 2015; Cooper and Brownell, 2016). Therefore, we hypothesize that active-learning classes can provide a greater number of opportunities to build immediacy between instructors and students. However, there are few studies that have explored instructor immediacy in the context of active-learning classrooms. In one study, Seidel and colleagues (2015) explored "instructor talk," a verbal immediate behavior, in an active-learning classroom. Instructor talk refers to any language used by an instructor that is not directly related to the course concepts, but instead focuses on creating the learning environment (Seidel et al., 2015). The authors of this study hypothesized that types of instructor talk, such as demonstrating respect for student and sharing personal experiences, may increase instructor immediacy in active-learning classrooms.

While the literature suggests that immediate instructor behaviors can lead to positive student outcomes broadly, we are unaware of any studies that have specifically examined the impact of an instructor knowing a student's name. Despite this lack of evidence, learning student names is frequently recommended as a simple instructional practice to build immediacy with students (Gorham, 1988; Page, 2004; Zakrajsek, 2007; Chambliss, 2014). Instructors of small-enrollment courses are often able to follow this recommendation and can learn some to all of the student names in their courses. However, it is unclear whether instructors of large-enrollment courses commonly learn student names. While there are rare examples of highly immediate college instructors who report learning hundreds of student names in large classes (Tanner, 2011), we assume that many instructors of large-enrollment courses resign themselves to the reality that they will not learn most student names in their courses. If instructors learn only a few names, it is also unknown which student names are learned by instructors. Although studies suggest that males are more likely to speak out and be remembered by their peers in large-enrollment biology courses (Eddy, Brownell, et al., 2014; Grunspan et al., 2016), we do not know whether this affects which student names are known by instructors. More specifically, it is unknown whether student identities such as gender, race/ethnicity, or college generation status influence which names instructors learn. Finally, since there are no studies that have examined the impact of using student names in the context of a large-enrollment undergraduate classroom, we do not know whether students in large-enrollment courses would even perceive benefits from an instructor knowing their names.

While the large numbers of students in high-enrollment courses make learning student names difficult, there are a number of strategies that instructors can use to be able to use student names, even if they do not actually know the student's name. One such strategy is having students display their names in class via name tents, a folded piece of card stock with a student's name written on it, so that instructors can use their names when interacting with the students (Tanner, 2011, 2013). Not only can name tents help instructors learn student names, they can help instructors call students by name even when the instructor does not know the student's name. This presents the question of whether students benefit from an instructor using their names or whether an instructor actually needs to know a student's name.

In this study, we explored student perceptions of instructors knowing their names in a large-enrollment undergraduate biology course that was taught in an active-learning way. This study is novel, in that we know of no other study that has linked student perception of instructors using names to student affective gains. Further, we know of no other study that has explored the use of names in a large-enrollment course. Our specific research questions were as follows:

1. To what extent do students perceive that instructors of large-enrollment undergraduate biology courses know their names, and does it align with whether an instructor actually knows their names?

a. To what extent do demographic characteristics predict which students perceive that instructors know their names?

b. To what extent do demographic characteristics predict which student names are actually known by an instructor?

2. Why, if at all, do students think that it is important to have their names known in a large-enrollment biology course?

3. How do students perceive that an instructor learned their names?

\section{COURSE DESCRIPTION}

All data were collected from a large-enrollment, upper-level biology course with 185 students. The class was taught in an active-learning format; every class session included student-centered instruction, typically using a combination of clicker questions accompanied by peer discussion and group work using worksheets. The class met three times a week for 50 minutes each time. For 2 days each week, classes were held with all 185 students in a traditional stadium-seating lecture hall with two aisles. On 1 day each week, students attended a recitation section with approximately 60-70 students that was held in a scale-up classroom with round tables (see the Supplemental Material for classroom layouts).

The course was cotaught by two instructors with significant teaching experience. Both instructors were committed to using student-centered approaches to teaching. Students earned course points for participating during lecture and recitation, which encouraged students to attend every class. Students were incentivized to attend office hours by earning one extra credit point for every time they attended office hours. Multiple office hours were offered throughout the week, and extra opportunities were available the week before exams. A select group of 10 honors students met every other week outside of the scheduled class time to read primary scientific papers, and one instructor attended each session.

On the first day of class, each student was provided with a piece of brightly colored card stock and a marker and asked to make a name tent (see Figure 1 for an example). Students were asked to bring their name tents to class every day and display 


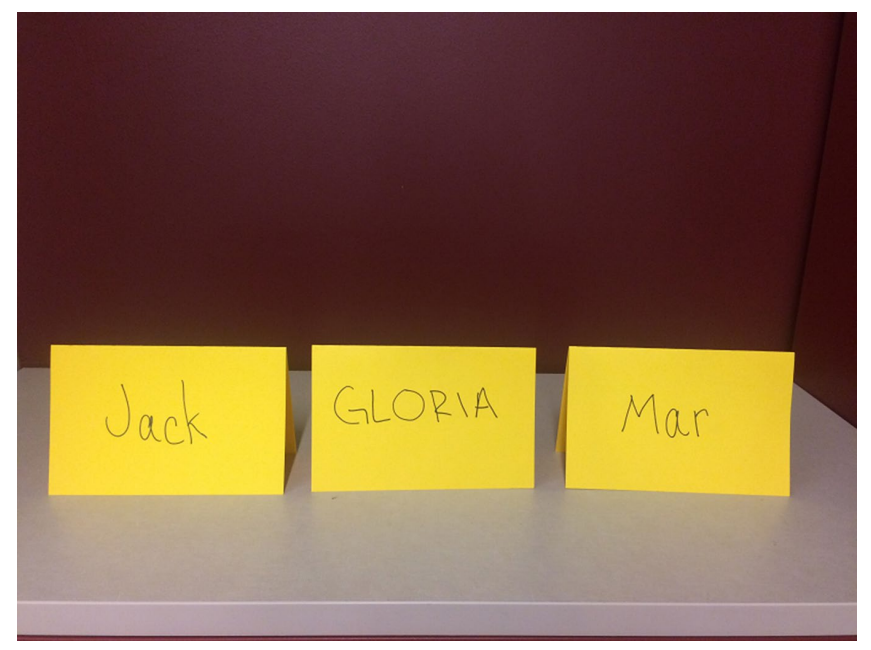

FIGURE 1. Example name tents. Students use markers to write their first names on a folded $8 \times 10$ inch piece of card stock.

them on their desks. Throughout the course, students were greeted by teaching assistants as they came into class and were reminded to take out their name tents. Additionally, the first lecture slide of most lectures reminded students to display their name tents. The instructors brought the materials to make new name tents to every class; if students forgot to bring their name tents, they were invited to make a new one at the beginning of the class period.

\section{METHODS}

\section{Data Collection}

Precourse Survey. During the first week of class, students completed a survey that asked about their prior experiences in large-enrollment biology courses. Large-enrollment courses were defined as courses of 50 students or more. Students were asked how likely it was that instructors of previous large-enrollment biology courses knew their names and responded on a four point Likert-scale ranging from very likely to very unlikely. These data were later collapsed into two categories, likely and unlikely. Student demographic information was also collected, including race/ethnicity, gender, and college generation status (see the Supplemental Material for a copy of the pre course survey).

Postcourse Survey. On the last day of class, we provided all students with a list of the two instructors for the course. We asked students to circle which of the instructors, if any, knew their names. If students thought an instructor knew their names, we asked them to describe how they thought the instructor learned their names. Finally, we asked students to please explain why instructors knowing their names was or was not important to them (see the Supplemental Material for a copy of the postcourse survey).

Interviews. Students in the course were offered several options to earn extra credit at the end of the semester. One of the ways in which students were able to earn the credit was to participate in an interview to give feedback on the course. To provide anonymity and to encourage students to speak freely about their experiences in the course, we assured students that instructors of the course would never listen to the interviews or associate their names with their responses. We designed interview questions to explore student conceptions of affective instructional practices, including instructors knowing student names. We created interview questions based on the findings of Seidel and colleagues (2015) and preliminary data collected from three sources during the previous term: student nominations for one of the instructors for a teaching award, general feedback from the students about what they had liked and disliked about the course, and formal student evaluations. We asked students whether they felt the instructors fostered relationships with students, built a classroom community, and cared about student success. If students indicated that one or both of the instructors established relationships with students, built a classroom community, or cared about student success, we asked the students how they thought the instructor did so. At the end of the interviews, we also asked students if they thought that either of the instructors knew their names. If students reported that they perceived an instructor knew their names, we asked them how they thought the instructor learned their names. We asked all students whether or not having their names known was important to them and what their opinions were of using name tents in class. In the interviews, we asked students the same set of questions for each instructor, and we combined those responses, because we are interested in how students perceive and interact with the instructors generally. The interview questions that were analyzed are provided in the Supplemental Material.

Student Name Identification. Within 3 days of the last day of class, each instructor was asked to identify the first names of students in the class. Each instructor was individually presented with a photo roster of the class with the names of students removed. The instructors looked at individual pictures of all students and were asked to name as many students as they could. This information was recorded into an Excel spreadsheet.

This study was done in accordance with an approved IRB protocol.

\section{Data Analysis}

Responses to Postcourse Survey. We began by analyzing student responses to the postcourse survey. We used grounded theory to identify themes from the student responses to the question "Please explain why instructors knowing your name is or is not important to you" (Glaser et al., 1968). Constant comparison methods were used throughout the analysis (Glesne and Peshkin, 1992). Quotes that were assigned to themes were gathered together and compared with one another throughout the analysis. This iterative comparison of quotes was meant to ensure that the description of the theme adequately represented all quotes within the same group and that the quotes were not different enough from one another to warrant a separate category. As a result of this process, we created a coding rubric (see Supplemental Table 1 for coding rubric).

Three of the authors (K.M.C., B.H., and S.E.B.) coded all student survey responses together and came to consensus when they disagreed. To establish that the coding scheme was reliable and could be used to replicate the results by other researchers, another author (A.K.) independently coded $25 \%$ of the 
statements coded by the other authors in the final round of coding, and the two results were compared. The authors had a consensus estimate of 99\% (Stemler, 2004).

Analysis of Interviews and Data Triangulation. All interviews were transcribed and anonymized to protect student identities. We used a combination of grounded theory and content analysis to identify interesting themes that emerged from the interviews. Additionally, we used content analysis on responses to the interview question about whether an instructor knowing a student name was or was not important, using the previously established rubric. The purpose of analyzing student answers to this question was to see whether student responses could be coded into the themes that were already established by analysis of the postsurvey question, or whether new themes would emerge. All student responses fell into at least one of the nine previously established themes, and no new themes emerged. To triangulate and further validate our findings, we analyzed student interview responses to questions about affective elements of the course to determine whether students mentioned instructors knowing their names. One author (B.H.) reviewed each question in every interview and identified whether students mentioned the classroom practice of knowing student names as part of their responses.

Statistical Analyses. Previous literature suggests that students may be more or less likely to have their names known based on their academic ability level, gender, race/ethnicity, and college generation status (Terenzini et al., 1996; Eddy, Brownell, et al., 2015; Grunspan et al., 2016). Therefore, we used this hypothesis to inform a generalized linear model. Using generalized linear modeling, we explored whether student prior academic ability, gender, race/ethnicity, and college generation status predicted whether students reported that they were likely to have their names known in previous large-enrollment biology courses, whether students perceived their names were known by an instructor, and whether a student's name was actually known by an instructor. The models are described in Table 1.

\section{RESULTS}

\section{Class Demographics}

In this course, $59 \%$ of students identified as female, $40 \%$ as male, and $1 \%$ as other. Sixty-two percent of students identified as white; $13 \%$ as Hispanic, Latin@, or Spanish origin; 7\% as Asian; $6 \%$ as Black or African American; $1 \%$ as American Indian or Alaska Native; $9 \%$ as other; and $2 \%$ declined to state. Twenty-four percent of students identified as a first-generation college student, $74 \%$ identified as a continuing generation college students, and $2 \%$ declined to state.

Finding 1: While Most Students Report That It Was Unlikely to Have Their Names Known in Previous Large-Enrollment Biology Courses, 75\% Report That an Instructor of This Course Knew Their Names

Likelihood of Student Name Known in a Previous Large-Enrollment Biology Course. Of the 185 students enrolled in the course, $171(92.4 \%)$ responded to the precourse survey during the first week of class, and 157 of these students (91.8\%) reported previously having been enrolled in a large-enrollment biology course. Of these 157 students, 125 (79.6\%) reported that, considering all of the large-enrollment biology courses they had previously been enrolled in, it was unlikely that an instructor knew their names during the course. Only 32 (20.4\%) students reported that it was likely that an instructor knew their names during previous courses (Figure 2a).

We explored whether student prior academic ability (measured by cumulative grade point average [GPA] at the beginning of the semester) or student social identities, including gender, race/ethnicity, and college generation status, predicted whether students were likely to report having their names known in previous large-enrollment biology courses. We found

TABLE 1. Results of models that explore whether student demographic characteristics predict (a) whether students perceive that it is likely that instructors of previous large-enrollment biology courses knew their names, (b) whether students perceive that instructors of this large-enrollment biology course know their names, and (c) whether an instructor of this large-enrollment biology course actually knew the student's name ${ }^{a}$

\begin{tabular}{|c|c|c|c|c|c|c|}
\hline \multirow[b]{2}{*}{ Identity } & \multicolumn{2}{|c|}{$\begin{array}{l}\text { a. Likely to report name } \\
\text { previously known }\end{array}$} & \multicolumn{2}{|c|}{$\begin{array}{l}\text { b. Student perceives name is } \\
\text { known by instructor }\end{array}$} & \multicolumn{2}{|c|}{$\begin{array}{l}\text { c. Student name actually } \\
\text { known by instructor }\end{array}$} \\
\hline & $\begin{array}{c}\text { Regression } \\
\text { coefficient } \pm \text { SE }\end{array}$ & $p$ Value $^{\mathrm{b}}$ & $\begin{array}{c}\text { Regression } \\
\text { coefficient } \pm \text { SE }\end{array}$ & $p$ Value & $\begin{array}{c}\text { Regression } \\
\text { coefficient } \pm \text { SE }\end{array}$ & $p$ Value \\
\hline Intercept & $-4.0 \pm 1.4$ & 0.00517 & $0.13 \pm 1.18$ & 0.912 & $0.10 \pm 0.45$ & 0.674 \\
\hline Prior GPA & $0.77 \pm 0.40$ & 0.05302 & $0.46 \pm 0.35$ & 0.197 & $0.01 \pm 0.01$ & 0.267 \\
\hline Gender: female & $-1.05 \pm 0.46$ & 0.02270 & $-0.12 \pm 0.43$ & 0.794 & $-0.35 \pm 0.36$ & 0.321 \\
\hline $\begin{array}{l}\text { Race/ethnicity: } \\
\text { underrepresented minority }\end{array}$ & $0.24 \pm 0.56$ & 0.66732 & $-0.65 \pm 0.46$ & 0.159 & $-0.39 \pm 0.41$ & 0.334 \\
\hline $\begin{array}{l}\text { College generation status: } \\
\text { first-generation }\end{array}$ & $0.80 \pm 0.67$ & 0.23605 & $-0.03 \pm 0.48$ & 0.947 & $-0.19 \pm 0.40$ & 0.637 \\
\hline
\end{tabular}

aThe first model explores whether students' prior academic ability, gender, race/ethnicity, or college generation status predicts whether they perceived it was likely or unlikely that instructors in previous large-enrollment biology courses knew their names. Model a: name.previously.known $\sim$ prior.gpa + gender + race + college.gen The second model explores whether students' prior academic ability, gender, race/ethnicity, or college generation status predicts whether they perceive that an instructor in this class knew their names. Model b: instructor.perception $\sim$ prior.gpa + gender + race + college.gen. The third model explores whether a student's prior academic ability, gender, race/ethnicity, or college generation status predicted whether an instructor actually knew their names. Model c: name.actually.known $\sim$ prior.gpa + gender + race + college.gen.

${ }^{\mathrm{b} B o l d e d} p$ values are significant. 


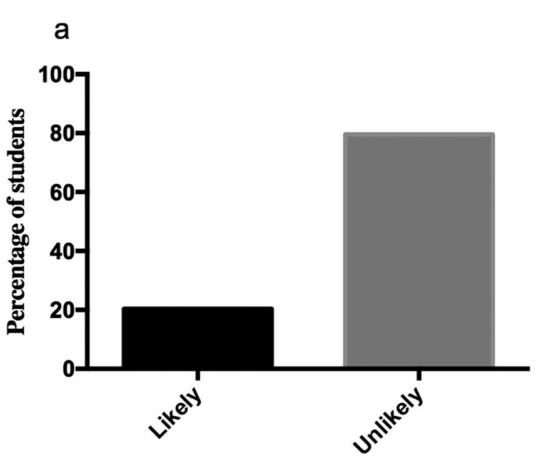

Student perceptions that their names were known by instructors of previous large enrollment biology courses

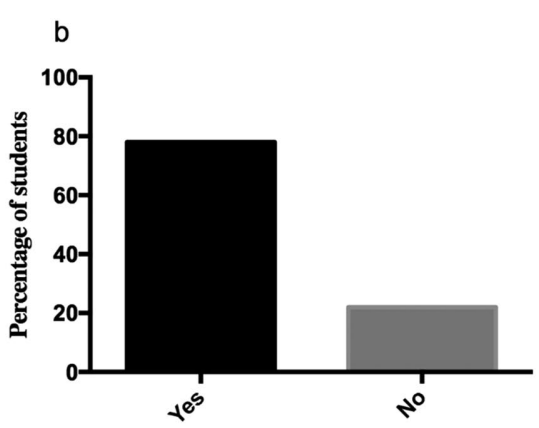

Student perceptions that their names were known by an instructor of this course

FIGURE 2. (a) Considering all previous large-enrollment biology courses that students had been enrolled in, 125 students (79.6\%) reported that it was unlikely that an instructor knew their names during a course, and only 32 students $(20.4 \%)$ reported that it was likely that an instructor knew their names during a course. (b) In considering this course, 136 students $(78.2 \%)$ perceived that an instructor of this course knew their names, and 38 students (21.8\%) reported that an instructor of the course did not know their names.

that female students were significantly (2.9 times) less likely than male students to report that it was likely that an instructor in previous large-enrollment biology courses knew their names (Table 1a), but we did not observe differences based on prior academic ability, race/ethnicity, or college generation status.

Perception of Whether Student Name Was Known in This Course. Of the 185 students originally enrolled in the course, 174 students (94\%) responded to the postcourse survey. Of these 174 students, 136 (78.2\%) perceived that an instructor of this large-enrollment upper-level biology course knew their names, and $38(21.8 \%)$ perceived that theirs name were not known (Figure 2b). We examined whether student prior academic ability, gender, race/ethnicity, and college generation status predicted whether students perceived that an instructor knew their names. We found that none of these variables predicted whether students perceived that their names were known by an instructor of this course (Table 1b). Therefore, despite female students being less likely to perceive that their names are typically known in large-enrollment biology courses, they were just as likely as male students to perceive that their names were known in this course.

Which Names Instructors Actually Knew. Even though 136 students (78.2\% of the class) perceived that their names were known, instructors were only able to name 92 students (52.9\% of the class) when they looked at deidentified roster photos of the students (Figure 3 ). Five students (2.9\% of the class) perceived that an instructor did not know their names, despite the fact that an instructor actually knew their names, and 33 students $(19.0 \%)$ correctly assumed that their names were not known by an instructor (Figure 3). Therefore, of the 136 students who perceived that their names were known, instructors actually knew 87 of these students' names $(64.0 \%$ of students who perceived their names were known), which means that 49 students (28.2\% of the class) perceived that an instructor knew their names when they actually did not (Figure 3). This implies that instructors do not always have to know student names in order for students to believe their names are known. We examined whether student prior academic ability, gender, race/ethnicity, and college generation status predicted whether an instructor actually knew student names. We found that none of these variables predicted whether a student's name was actually known by an instructor (Table 1c).

\section{Finding 2: Students Report That} Instructors Knowing Their Names Is Important to Them

Students Perceive That It Is Important for Instructors to Know Their Names. Of the 174 students who completed the postcourse survey, 157 students (90.2\%) responded to a question that asked whether they thought it was important that instructors knew their names. Of these students, 134 (85.4\%) said it was important for instructors to know their names, while 23 (14.6\%) said it was not important (Figure 4).

Why Students Perceive an Instructor Knowing Their Names Is Important. We asked students who reported that it was important that an instructor knows their names to explain why it was important to them. We used grounded theory to code student responses, which generated nine reasons that were mentioned by at least $5 \%$ of students in the course (Glaser et al., 1968). We chose $5 \%$ as a cutoff for reporting results, because that meant that at least six students perceived that theme as a benefit. Because this is an exploratory study, we wanted to be as inclusive as possible in our initial category formation. Because students were able to write as much as they wanted in response to the open-ended question, some students mentioned multiple reasons. Seventy-two students (54\%)

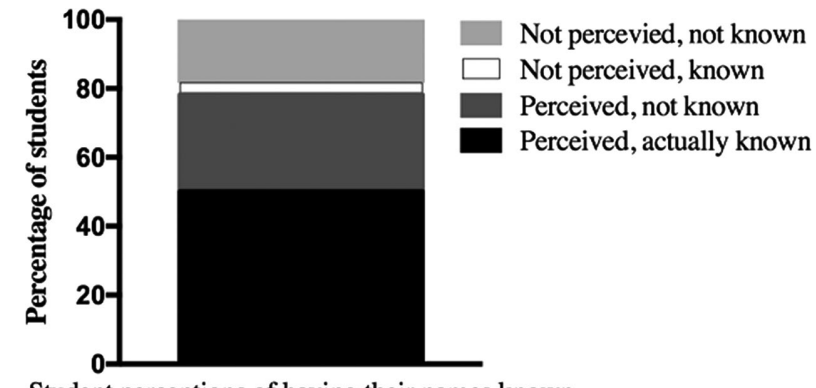

Student perceptions of having their names known and whether instructors actually knew their names

FIGURE 3. Of the 174 students who completed the postcourse survey, 87 students $(50.0 \%)$ correctly perceived that an instructor of the course knew their names. An additional 49 students (28.1\%) perceived that an instructor of the course knew their names, but their names were not actually known by instructors. Five students (2.9\%) incorrectly perceived that their names were not known by an instructor, when they actually were, and 33 students (19.0\%) correctly perceived that their names were not known by an instructor of the course. 


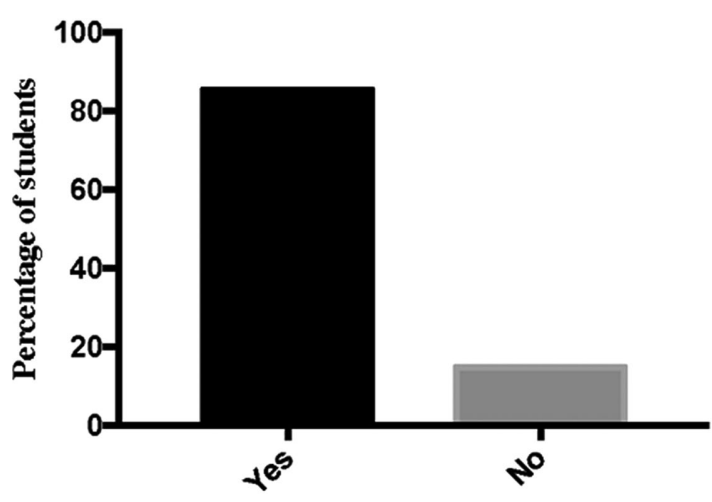

Student self-report of whether an instructor knowing their name is important to them

FIGURE 4. Student responses to the question "Is it important that professors know your name?" Eighty-five percent of students responded that it was important to them than an instructor knows their names.

reported out more than one reason as to why having their names known by an instructor is important to them, and the average number of reasons per student was 1.66. However, students were not instructed to make an exhaustive list, so it is likely that we are underestimating the number of students who perceive that a particular reason is important. Detailed descriptions of each category can be found in Supplemental Table 1.

Students reported that having their names known by an instructor affects their attitudes about the course (Table 2). The most common student response for the importance of knowing student names was that the students feel valued in the course (41 student responses, 30.6\%). Additionally, 26 students (19.4\%) mentioned that, when an instructor knows their names, they feel more invested in the course. Students also indicated that having their names known affects their behavior in the course (Table 2). Twenty-six students (19.4\%) said that they would feel more comfortable seeking help from the instructor, and 16 students (11.9\%) mentioned that they would feel more comfortable talking to the instructor about topics unrelated to the content, such as scheduling conflicts or personal struggles. Sixteen students (11.9\%) said that they felt as though they perform better in a course when their names are known by an instructor.

Students also described how having their names known affects how they perceive both the course and the instructor (Table 2). Thirty-six students (26.9\%) wrote that, when an instructor knows their names, it makes them feel as though the instructor cares. Interestingly, 31 students (23.1\%) mentioned that it helps to build student-instructor relationships; however, only nine students $(6.7 \%)$ reported that having their names known would increase the chances that an instructor of the course would mentor them or provide them with a letter of recommendation. Students also perceived that when instructors know student names it helps to build classroom community (19 student responses, 14.2\%).

To triangulate student responses on the postcourse survey, we analyzed a set of student interviews aimed at exploring student perceptions of the affective components of this course.
Specifically, we asked whether students felt as though the instructors of the course cared about their success, built relationships with students, and built classroom community. Students were also asked whether instructors structured the class so that all students could succeed, and whether they felt that the instructors cared about their success after the course ended. We analyzed these interviews to see whether students mentioned instructors knowing student names during their responses to these questions. Notably, 25 students (73.6\%) said that instructors built relationships with students in the class by knowing their names, and 16 students (47.1\%) said that instructors knowing student names contributed to why they thought the instructors cared about their success in the course (Table 3). Furthermore, seven students (20.6\%) said that instructors knowing student names contributed to the instructors' abilities to build classroom community (Table 3 ).

\section{Finding 3: Students Report a Variety of Ways That They Perceive Instructors Learn Their Names}

Owing to the large number of students in this class who perceived that their names were known by instructors and how important it seemed to students for instructors to know their names, we wanted to explore student perceptions of how instructors learned their names in a large-enrollment class.

Students perceived that instructors learned their names in a variety of different ways. Of the 136 students who perceived that an instructor of the course knew their names, 133 (97.8\%) explained how they thought an instructor learned their names. Students could provide multiple reasons for how one or both instructors learned their names. Students reported that they thought the instructors learned their names through methods both inside and outside the classroom (Table 4). For example, 58 students (43.6\%) cited that they thought their names were learned through the use of name tents. Notably, this class was taught in an active-learning way, which provided ample opportunities for instructors to walk up and down the aisles of the classroom and use the name tents when interacting with students during structured student discussions. Forty-six students (34.6\%) referenced in-class interactions with an instructor during lecture and 16 students (12.0\%) mentioned interactions with an instructor during recitation as ways that instructors learned their names. The instructors of this course often arrived early to the classroom and would stay late to interact with students. Fifteen students (11.3\%) reported that they thought their names were learned through interacting with an instructor before or after class. Finally, a small subset of eight students $(6.0 \%)$ mentioned that they thought their names were known because they sat near the front of the classroom.

Students also mentioned that instructors may have learned names through interactions that occurred outside the classroom. For example, 44 students (33.1\%) mentioned that they perceived that an instructor learned their names in office hours, and 17 students $(12.8 \%)$ responded that their names were learned through email exchanges with the instructors. Nine students $(6.8 \%)$ reported that an instructor learned their names because of their participation in the course journal club that was available to honors students, and six students (4.5\%) responded that the instructors already knew their names from previous interactions or events unrelated to this course. Additionally, eight students (6.0\%) reported that they experienced 
TABLE 2. Student perceive that having their names known by an instructor is important to them for nine distinct reasons that fall into three larger categories, including affects student attitudes about the course, affects student self-reported behavior, and affects how the student perceives the course or the instructor

$\begin{aligned} & \text { Why it is important that } \\ & \text { instructors learn your name? }\end{aligned}$
$\begin{aligned} & \text { \% Student } \\ & \text { responses }(n=134)\end{aligned}$

Student feels more invested in the course

"Instructors knowing your name can be rather inspiring for a student to want to achieve more in class." -Graham
"I feel like I'm just a face in the crowd most of the time, even in classes where the teacher is really excited about teaching and helping students understand. Knowing my name makes me feel more noticed and welcome."-Jamie

"When I feel that personal connection with the instructors it makes me want to do better in the class as well, it's almost as if I'm extra accountable."-Lloyd

\section{Affects student self-reported behavior}

Student feels more comfortable getting help

19.4

"[An instructor knowing my name] makes me feel more comfortable asking questions/getting help on subjects."-Whitney

Student feels more comfortable talking to the instructor

"Often students think that instructors don't care about personal things going on in life that can affect a student's work and [when instructors know your name] it can be easier to share if you had a good day/bad day/etc."-Jewel

Student feels enhanced performance in the course or confidence in the material
"I think having an instructor know the student names can only boost student performance."-Rick
"[An instructor knowing my name] makes it easier to motivate myself to come to office hours/get help with concepts if I know the professor on a level higher than just 'my professor."'-Jorge

"[Instructors knowing my name] definitely made me more confident about approaching the professor when I had a scheduling conflict."-Tracey

"[Instructors knowing my name] creates a more comfortable dialogue and therefore increases confidence in lecture material."-Grayson

\section{Affects how the student perceives the course or the instructor}

Student feels an instructor cares

26.9

"The instructors knowing my name was important because it made me feel like they cared. If they cared enough to remember my name in such a large class, it showed me that they cared about my experience in the class and education."-Kaylie

Student feels it builds student-instructor relationships

Student feels it builds classroom community

"When instructors know your name, they kind of get to know you on a more personal level and this could make learning a better experience."-Carolyn

"[Instructors knowing student names] is important to me because it provides a more welcome atmosphere where students feel comfortable sharing their ideas even if they are wrong or way off."-Delores

Student feels that instructors are more likely to provide student with letter of recommendation or mentoring
6.7

"[Instructors knowing my name] is essential because in the case I may need a reference or for someone to recommend me for either a lab or any sort of job opportunity. Also they are great sources of career advice and guidance in my educational and biological career."-Charles
"[Instructors knowing student names] shows that the instructors care about all of the students individually and they have invested interest in ensuring that everyone feels welcome and that they have every opportunity to succeed in the course." -Bettie

"[Instructors knowing student names] indicates that more personalized one-on-one interaction has occurred which will likely lead to greater mutual respect."-Steven

"[Instructors knowing student names] is important to create a sense of community in the classroom, which is especially important for active learning."-Tyson

"Getting to be known by my professor has generally been something that's important to me. I like building connections and enjoy opportunities for greater mentorship."-Denise 
TABLE 3. Percent of students who brought up instructors knowing their names in response to interview questions about affective components of the course

\begin{tabular}{|c|c|}
\hline Interview question & $\begin{array}{l}\text { Percentage of interviewees } \\
\text { who mentioned an instructor } \\
\text { knowing their names }(n=34)\end{array}$ \\
\hline $\begin{array}{l}\text { Do you feel that the instructors care } \\
\text { about your success and why? }\end{array}$ & 47.1 \\
\hline $\begin{array}{l}\text { Do you think that the instructors of } \\
\text { this course built relationships } \\
\text { with students? If so, how? }\end{array}$ & 73.6 \\
\hline $\begin{array}{l}\text { Do you think that the instructors of } \\
\text { this course built a classroom } \\
\text { community? If so, how? }\end{array}$ & 20.6 \\
\hline $\begin{array}{l}\text { Do you think that the instructors of } \\
\text { this course structured the class so } \\
\text { all individuals could succeed? If } \\
\text { so, how? }\end{array}$ & 2.9 \\
\hline $\begin{array}{l}\text { Do you feel that instructors care } \\
\text { about your success after this } \\
\text { course and why? }\end{array}$ & 2.9 \\
\hline
\end{tabular}

extenuating circumstances, such as a personal emergency, that required them to interact with an instructor, which caused the instructor to learn their names.

We also explored whether students who perceived that their names were known by an instructor when they actually were not had similar responses as students whose names were actually known by an instructor. There were no significant differences among the ways that the two groups of students perceived that instructors learned their names, with only one exception. A significantly greater percentage of students whose names were actually known by an instructor perceived that their names were learned in office hours, compared with the number of students who perceived that their names were known, but were not actually known by an instructor $(p<0.05$; see Supplemental Table 2 for further information).

\section{Finding 4: Name Tents Were Used by Instructors to Build Relationships with Students, but Were Also Used by Students to Build Relationships with One Another}

Notably, the highest percentage of students who perceived that their names were known reported that instructors learned their names by using name tents on the postcourse survey. The instructors of this course purposefully implemented this practice in hopes of using student names as a way to create a moreinclusive classroom community (Tanner, 2011, 2013). We explored this instructional practice further with the student interviews to better understand students' perceptions of the name tents.

Student interview responses corroborated our postcourse survey responses, which illustrated that students perceived that instructors used name tents to learn their names.

\section{Interviewer: "What is your opinion of the name tents?"}

Kaylie: "I think the name tents are good just because the professor can learn your name. Even if you don't go to office hours, they'll learn your name."
Sam: "I think the instructor learned my name from the name tents. I think they were probably pretty helpful. The instructors would come around and say 'Hey [Sam], what do you think about this?' After a while I would imagine they just kind of learned my name without the name tent."

While we had anticipated that the name tents likely improved communication between instructors and students, we did not initially consider how the name tents would influence communication among students. However, students found the name tents particularly useful when they were asked to interact with other students in this active-learning classroom. For example, students such as Erika talked about how being called by their names improved communication between themselves and other students.

Erika: "I had my name tent out a couple weeks ago, and the person sitting next to me called me by my name. I turned around. It makes me respond better, because they call you by your name instead of like, 'Hey.' Some random person is talking to you, and they just want to discuss a worksheet question. When they call your name-I don't know what it is-it makes me want to have more communication with them, better communication since they call you by your name."

Other students talked about how they used the name tents to call other students by name. Courtney mentioned how she thinks that interactions with other students are more personal when you can call them by name.

Courtney: "Yes, [the name tents] are helpful because especially during the clicker questions when [the instructors] are like, 'Talk to your partner,' it's just easier if you know who you're talking to and you can call them by their name. It's just a better way to know people. It's more personal than just, 'Hey, you."'

Another student, Allen, talked about how, if a student answers a question during whole-class discussions, the name tents can be used by everyone in the course to learn that student's name. He mentioned that using student names could help students to explore one another's understanding of biology content or even to find a new study partner.

Allen: "[Using name tents] was interesting for everyone to be able to know you. Maybe if someone agreed with your idea, they could ask you to further your understanding. If someone disagreed, maybe they could come up to you later in recitation and say, 'This is what I think.' I think it was a good idea just to get to know people in an indirect way, so that if you thought someone had a good idea, that you can go up to them. Maybe you think that they might be a good study partner. Maybe you think they would be good in recitation. I think that sharing of ideas would be good."

One student, Kelsey, recognized that using other students' names is a part of building classroom community. She implied that using name tents might be particularly helpful in active-learning classrooms, where students have more frequent interactions with other students. 
TABLE 4. Students perceived that instructors learned their names in a variety of ways, both inside and outside the classroom

\begin{tabular}{|c|c|}
\hline $\begin{array}{l}\text { Student perception of how } \\
\text { instructors learned their } \\
\text { names }\end{array}$ & $\begin{array}{l}\text { \% Responses of students } \\
\text { with name known } \\
(n=133)\end{array}$ \\
\hline
\end{tabular}

How students perceived names were learned inside the classroom

Name tents

Interactions during recitation

Interactions before or after class

6.0

"I sat up front on the very first day of class."-Eugene my name. This happened a few of paper."-Annie

"Talk to and see the instructor before class."-Jorge

Sitting near the front of the
"The instructors were very persistent in using the yellow name tents and would use them whenever they had the chance. They made an effort to learn names by using the name cards."-Daniel

"One instructor knows my name but I'm not sure why because, I always forget my name tent. She talks to me in class though, so maybe that's why."-Laura

"The instructor would talk to me in recitation and would remember who I am from those instances."-Kaylie times, which made it more personal rather than just reading it off a piece

How students perceived names were learned outside the classroom

Student attends office hours $33.1 \quad$ "I think the instructor knows my name because I have gone to his/her office hours a few times."-Dionne

Email exchange between student and instructor

"I email one instructor a lot and she/he hasn't blocked me yet, so guess that is a good thing."-April

Student attends journal club for honors students

Extenuating circumstances

"Yes, from class and from doing the honors journal club."-Shane

"Reached out to one instructor near the beginning of the semester in order to reschedule an exam, had plenty of face-to-face interaction; has called me by name on future occasions."- Clay

Student was previously known by an instructor

"One instructor was originally on my camp for first-year students this past summer and was able to remember my name on the first day of class."- Donald
"One of the instructors took the time before class to talk to me once and see how my semester was going." - Bailey

"I sat at the front of the class most of the semester..."-Whitney
"Because I visited the instructor's office to talk about exam scores, research, life, etc."-Ioulia

"Probably knew my name from emails I sent the instructor."- Autumn

"By my participation in the honors [reading group]."-Jane

"At the beginning of the semester, I had frequent fainting spells right before the first exam-the instructors let me make-up the exam but not before a couple emails." - Erika

"I had one of the instructors as my instructor in a first-year seminar; on the first day, she recognized me."-Rodger
Kelsey: "There's a girl that was in my breakout session and we worked during class and early on, once or twice I forgot her name and I would see her name tent, and even if I didn't use her name right then, I remember it now, and I'll probably continue to remember it. She's probably the closest thing I have to being a part of a biology community, just because we worked together so frequently. And knowing her name is part of building a community."

Finding 5: Some Students Resisted Name Tents until They Realized the Benefits of Having Their Names Known or Learning Other Students' Names

Historically, classroom practices focused on learning student names have been implemented in primary education (Page,
2004) or in small-enrollment classrooms (Zakrajsek, 2007). We were curious about students' reactions when name tents were first implemented in this large-enrollment upper-level college class. In the student interviews, we asked students what they thought about using the name tents and whether their opinions changed over the course of the semester. Many students said that in the beginning of the semester they thought that the name tents were childish and did not want to use them. They indicated that it was normal to be invisible in a high-enrollment course and did not see the point in writing their names on pieces of card stock. However, nearly all students who we interviewed reported that their opinions became more positive after they realized the benefits of either having their names used or 
using other students' names. For example, Naomi talks about how she did not initially understand the purpose of the name tents, but eventually realized how name tents could be used to help build connections with others in class.

Interviewer: "What was your opinion of the name tents at the beginning of the semester?"

Naomi: "In the beginning I was kind of 'OK, this is going to be awesome."”

Interviewer: "Sarcastically awesome?"

Naomi: "Yeah, it was sarcastically awesome because I wasn't expecting it and it was kind of like 'Why would we have name tags in lecture? I don't really understand.' Then after a while when you realize like 'Oh, [the instructors] know your name and it builds connections,' I actually liked the name tent. If I get another class that has name tents on the first day I would be more excited and it wouldn't be a sarcastic excitement, it would be an actual excitement. So yeah, name tents ended up being a good thing."

Similarly, Carolyn's opinion of the name tents became more positive once she realized that the name tents could be useful when engaging others in class discussion.

Carolyn: "At the beginning [of the course] I thought the name tents were silly just because there was really no point, and because I knew who I was going to sit with. But it helped engaging with groups nearby when you were going over clicker questions. It was helpful when I would try to engage with a group beside me, and I needed help with a question or I didn't know. I definitely would [use the name tents] if I couldn't get their attention, I would say one of their names."

Erika indicated that she began this course expecting that, because she did not know anyone, no one would care what her name was. However, by the end of the course, she recognized that she was able to communicate with her peers better and even found a study partner because she was able to address another student by name.

Erika: "I didn't understand why [the instructors asked us to use name tents]. There are always big lectures, and no one really cares what your name is. I thought it was pointless. I thought it was like a first day thing. Then it was like, 'No, every day bring your name tents.' It was different. I didn't like it at first, but I think it's important. Just knowing someone else's name will help you talk to them better. I found a study partner for the first test. Just calling people by names instead of saying, 'Hey, want to study later?' I just feel like it's better to actually call people by name instead of just saying, "Hey."'

Allen echoed that a student is not just a face in the crowd when someone else in class knows his or her name, and he grew to appreciate the benefit of getting to know others on a more personal level.

Allen: "I thought they were childish at first, and maybe they still are, but I think that's a good way of developing understanding and putting a face to a name. We're not just another student. You're not just another 'whatever.' Not robotic, but more of getting to know people on a personal level. I think names are personal."

\section{DISCUSSION}

While instructors knowing student names is generally promoted as a positive and inclusive classroom practice (Tanner, 2011), to our knowledge there are no studies that explore how this specific instructional practice affects students. We set out to explore this question in the context of a large-enrollment active-learning undergraduate biology class.

\section{Using Student Names: Important for Classroom Climate, Especially in Active-Learning Classrooms}

We found that the majority of students (85\%) felt as though instructors knowing their names was important. Students described that when instructors know their names, they feel more valued in the course and frequently mentioned that they feel as though they are more than just a face in a crowd. This finding aligns with literature suggesting that knowing student names can help create an inclusive biology classroom (Tanner, 2013).

Furthermore, this study suggests that using name tents may provide students with a more equitable experience in the classroom. Significantly fewer females reported that their names were likely to be known in previous large-enrollment biology courses, which is in alignment with previous studies that show that females are less comfortable speaking out in large-enrollment biology classes (Eddy, Brownell, et al., 2014) and that even when males and females are equally outspoken, male students tend to be more memorable (Grunspan et al., 2016). In contrast, we found no gender differences in who perceived their names were known by instructors or whose names were actually known by instructors in this specific course. We hypothesize that the use of name tents may have contributed to the similar percentages of males and females who perceived that their names were known and whose names were actually known by instructors in this course.

As instructors continue to follow national calls to transition traditional lectures into active-learning spaces (American Association for the Advancement of Science, 2011), students are being asked to interact with one another more frequently. More frequent social interactions among students during class have been shown to be correlated with students' higher sense of belonging, overall class enjoyment, and increased engagement during class (Sandstrom and Rawn, 2015). We found that students interacting with one another in this class used the name tents to improve communication and build community with other students. While previous research suggests that knowing student names is an important factor in building rapport between instructors and students (Frisby and Martin, 2010; Wilson et al., 2010; Lammers and Gillaspy, 2013), we are unaware of any studies that have explored how students using other students' names influences community building among students. Our data suggest that students prefer more personal interactions with their peers and not only appreciate when other students call them by name, but also value the opportunity to address others by name. Interestingly, many students 
also mentioned that using other students' names helped them to initiate or maintain friendships and find study partners, which could have broader implications for student sense of belonging and retention in college (Tinto, 1975, 1997; Sandstrom and Rawn, 2015).

\section{Explicit Instructor Talk about Using Names and Implementing Name Tents}

The instructors of this course made a concerted effort to use student names as much as possible and to be explicit about why they were having students use the name tents. This instructor talk (Seidel et al., 2015) about the name tents at the beginning of the semester seemed to impact student perceptions of the practice in a positive way, because instructors talked explicitly about using the name tents to learn student names, to build community, and to help the instructors get to know students in a large class. The instructors of the course felt that they would have had less student buy-in if they had told students to use the name tents without being transparent about their purpose (Seidel and Tanner, 2013). Further, the instructors continuously reinforced the use of name tents. Students made them on the first day of class, but a reminder to set out the name tents was on the first PowerPoint slide of most classes, and the instructor also verbally reminded students in most class periods. Materials to make extra copies of name tents were provided at each lecture, and this reinforcement was likely important for the students' continued use of name tents.

Using Student Names May Influence Student Performance Students reported that instructors knowing their names made them feel more comfortable approaching instructors for help and talking with instructors broadly or about subjects other than course material. Students who are more willing to seek help from instructors, particularly in large-enrollment courses, have been shown to be more motivated and perform higher on exams than students who are less likely to seek help (Karabenick, 2003). Furthermore, student-faculty interaction has been shown to positively predict students' grades and confidence in highly challenging college science courses (Micari and Pazos, 2012). These findings align with students' perceptions in this study that having their names known by an instructor also improved their performance in the course.

While there is some evidence to suggest that immediate instructor behaviors may positively influence cognitive learning (Kelley and Gorham, 1988; Christophel, 1990; Chesebro and McCroskey, 2001; Titsworth, 2001), it is difficult to determine the specific impact of this instructional practice on student performance. Because we did not identify when in the semester students perceived that instructors learned their names (e.g., day 1 or the day before the final), we were unable to determine whether students who perceived their names were known performed better in the course than students who did not perceive their names were known. We hypothesize that it is important to account for the amount of time that a student suspected his or her name was known. Furthermore, pinpointing at what time point a student perceives his or her name is known would be necessary to determine directionality. For example, with our current data set, it would be impossible to determine whether student perceptions of having their names known predicted office hour attendance or whether office hour attendance predicted student perceptions of having their names known. To begin to explore this question, we regressed students perceiving that their names were known at the end of the semester on overall exam performance in the course, controlling for prior GPA. We did not see any relationship between these two variables, but this is a coarse measure, and a more reductionist approach is planned for future studies (see Supplemental Table 3 for further information).

\section{Instructors Can Have a Positive Influence on Students, Even When They Do Not Actually Know Students' Names}

Our data show that, overwhelmingly, students are not used to having their names known in large-enrollment biology courses, but that it is possible for most students in large classes to perceive that an instructor knows their names. Importantly, this study suggests that instructors do not actually need to know a student's name in order for the student to perceive that his or her name is known. We feel that this is an encouraging finding for instructors tasked with teaching large-enrollment courses, because it implies that, while instructors may be limited in the number of names they can learn, the number of students they can positively influence is not necessarily bounded. When instructors make an effort to use student names in class, a student may perceive that an instructor knows his or her name, when in reality, the instructor is glancing at a student's name tent or worksheet for a reminder of the student's name. Anecdotally, the instructors of this course felt as though many students forgot that the name tents were visible to the instructors, because name tents became a standard part of classroom practice. This may have contributed to why students perceived that instructors knew their names when they actually did not. Notably, any student who perceived that an instructor knew his or her name could experience a number of the benefits students mentioned, including feeling more valued, more accountable to come to class, or more comfortable seeking help.

\section{The Effect of Immediate Instructor Behaviors on Student Experiences in Active Learning}

In this study, we conclude that one verbal immediate instructor behavior, using student names, positively influences student experiences in an active-learning classroom. However, additional studies are needed to explore the influence of other verbal and nonverbal immediate instructor behaviors on student affective and cognitive gains in active-learning courses. Courses taught in an active-learning way provide an important context in which to explore the effects of instructor immediacy. In traditional lecturing, there is often a physical separation between instructors teaching at the front of the room and students passively listening in their seats. However, student-centered active learning affords additional opportunities for instructors to practice immediate behavior; instructors in active-learning classrooms often walk up and down the aisles in large lecture halls and engage students in conversation. In this course, instructors practiced immediate verbal behaviors, such as providing positive feedback to students, as well as nonverbal behaviors, such as walking around the classroom while students engaged in group work. We encourage future research efforts to take a reductionist approach to explore how specific immediate instructor behaviors could influence students in active-learning classrooms. 
Using Student Names: A Low-Effort, High-Impact Practice

While there are many things that instructors can do to create an inclusive and welcoming classroom (Tanner, 2011), using student names is a relatively simple practice that appears to positively affect students in multiple ways. In this course, many students reported that they perceived that their names were known through the use of name tents. Card stock costs approximately \$20 for 250 sheets, and name tents take about a minute for students to make. Instructors do not need special training to use name tents, nor does their use take up much instructional time. This could be a relatively easy way for instructors to diminish the anonymity of large classrooms and simultaneously build community among students and between the instructor and students.

The second most prevalent way that students perceived that instructors learned their names was through office hours. The instructors of this course incentivized students to come to office hours by offering one point of extra credit (less than $0.1 \%$ of their overall grade). Thirty-two percent of students attended office hours, which likely also led to the large number of students who perceived that their names were known by an instructor. Instructors may want to consider incentivizing students to attend office hours to increase the chances of students perceiving that their names are known. However, this practice puts the responsibility on the student to come to office hours, which may favor more outgoing or confident students.

\section{Caveats}

This is work conducted in the context of one class at a single institution. While the findings are encouraging, more research needs to be done to explore the impact of using student names in courses with a greater number of students, different classroom layouts, and different instructors.

This large-enrollment course included 185 students, which we recognize is smaller than many other large-enrollment courses. It is possible that classes of $500+$ students may be so large that students would have much lower perceptions of instructors knowing their names, even if name tents were used.

Furthermore, the layout of a classroom likely influences instructor practices. In this course, instructors were able to move up and down aisles on both sides of the lecture classroom (see the Supplemental Material for classroom layouts), which helped in seeing name tents and using student names. Instructors who are not able to freely move about the classroom may have a harder time reading name tents. However, an alternative strategy in a classroom without aisles is to not allow students to sit in some rows so that instructors are able to use those rows to get closer to different groups of students.

The instructors of this course used a lot of instructor talk (Seidel et al., 2015) to explain the purpose of the name tents, and our data suggest that the instructors were generally perceived as approachable by students. Furthermore, the instructors of this course made the effort to be available to students before and after class, a practice that may not be possible for all instructors. Instructors with different immediate behaviors, personalities, and commitment to talking about name tents may have different impacts on students. This research needs to be replicated in classrooms taught by different instructors.

\section{NEXT STEPS}

This study is an exploratory study to see how, if at all, students are affected when they perceive that instructors know their names. Students in this study suggested that having their names known may influence student behavior such as attending office hours, asking questions, and coming to class. Further studies could explore whether student perceptions of instructors knowing their names actually influences these behaviors and performance in a course.

\section{CONCLUSION}

Does using a student's name in a large-enrollment course matter? We have found that students perceive it is important for multiple reasons and that instructors do not even need to know student names for students to benefit. This student quote summarizes the potential impact of this relatively simple instructional practice on students in a large-enrollment class:

Kelly: "I know there are close to 200 kids in this class and I'm not in any way a top student or someone special, but I sure felt like I was when the instructor knew my name."

In contrast to what the student thought, the instructor did not know her name and had read her name off the name tent. Yet it was enough for this student to feel special in her largeenrollment biology course.

\section{ACKNOWLEDGMENTS}

We thank the members of the Biology Education Research Lab at Arizona State University for their thoughtful comments and feedback on this article.

\section{REFERENCES}

Boldface names denote co-first authors.

American Association for the Advancement of Science (2011). Vision and Change in Undergraduate Biology Education: A Call to Action, Washington, DC. http://visionandchange.org/files/2013/11/aaas-VISchange -web1113.pdf (accessed 5 July 2016)

Chambliss DF (2014). Learn your students' names. Inside Higher Ed. www insidehighered.com/views/2014/08/26/essay-calling-faculty-members - learn-their-students-names (accessed 20 May 2016)

Chesebro JL, McCroskey JC (2001). The relationship of teacher clarity and immediacy with student state receiver apprehension, affect, and cognitive learning. Commun Educ 50, 59-68.

Christensen LJ, Curley KE, Marquez EM, Menzel KE (1995). Classroom situations which lead to student participation. Paper presented at the annual meeting of the Speech Communication Association, held November 1995 in San Antonio, TX.

Christophel D (1990). The relationships among teacher immediacy behaviors, student motivation, and learning. Commun Educ 39, 323-340.

Cooper KM, Brownell SE (2016). Coming out in class: challenges and benefits of active learning in a biology classroom for LGBTQIA students. CBE Life Sci Educ 15, ar37.

Eddy SL, Brownell SE, Thummaphan P, Lan MC, Wenderoth MP (2015). Caution, student experience may vary: social identities impact a student's experience in peer discussions. CBE Life Sci Educ 14, ar45.

Eddy SL, Brownell SE, Wenderoth MP (2014). Gender gaps in achievement and participation in multiple introductory biology classrooms. CBE Life Sci Educ 13, 478-492

Frisby BN, Martin MM (2010). Instructor-student and student-student rapport in the classroom. Commun Educ 59, 146-164. 
Glaser BG, Strauss AL, Strutzel E (1968). The discovery of grounded theory strategies for qualitative research. Nursing Res 17, 364.

Glesne C, Peshkin A (1992). Becoming Qualitative Researchers: An Introduction, White Plains, NY: Longman.

Gorham J (1988). The relationship between verbal teacher immediacy behaviors and student learning. Commun Educ 37, 40-53.

Grunspan D, Eddy SL, Brownell SE, Wiggins B, Crowe AJ, Goodreau S (2016). Males under-estimate academic performance of their female peers in undergraduate biology classrooms. PLoS One 11, e0148405.

Karabenick SA (2003). Seeking help in large college classes: a person-centered approach. Contemp Educ Psychol 28, 37-58.

Kelley DH, Gorham J (1988). Effects of immediacy on recall of information. Commun Educ 37, 198-207.

Lammers WJ, Gillaspy JA Jr (2013). Brief measure of student-instructor rapport predicts student success in online courses. Int J Scholar Teach Learn 7(2), 16

Mehrabian A (1971). Silent Messages, Belmont, CA: Wadsworth.

Menzel KE, Carrell LJ (1999). The impact of gender and immediacy on willingness to talk and perceived learning. Commun Educ 48, 31-40.

Micari M, Pazos P (2012). Connecting to the professor: impact of the studentfaculty relationship in a highly challenging course. Coll Teach 60, 41-47.

Moore A, Masterson JT, Christophel DM, Shea KA (1996). College teacher immediacy and student ratings of instruction. Commun Educ 45, 29-39.

O'Sullivan PB, Hunt SK, Lippert LR (2004). Mediated immediacy: a language of affiliation in a technological age. J Lang Soc Psychol 23, 464-490.

Page B (2004). Teacher feature: learning your student's names: fun, fast, easy, and important. Teacher's Net Gazette 3(8). www.teachers.net/ gazette/AUG02/page2.html (accessed 5 July 2016).

Richmond VP (1987). The relationship between selected immediacy behaviors and cognitive learning. Commun Yearbook 10, 574-590.

Rocca KA (2004). College student attendance: impact of instructor immediacy and verbal aggression. Commun Educ 53, 185-195.

Sandstrom GM, Rawn CD (2015). Embrace chattering students: they may be building community and interest in your class. Teach Psychol 42, 227 233.
Seidel SB, Reggi AL, Schinske JN, Burrus LW, Tanner KD (2015). Beyond the biology: a systematic investigation of noncontent instructor talk in an introductory biology course. CBE Life Sci Educ 14, ar43.

Seidel SB, Tanner KD (2013). "What if students revolt?" Considering student resistance: origins, options, and opportunities for investigation. CBE Life Sci Educ 12, 586-595

Stemler S (2004). A comparison of consensus, consistency, and measurement approaches to estimating interrater reliability. Pract Assess Res Eval 9, 1-11.

Tanner KD (2011). Moving theory into practice: a reflection on teaching a large introductory biology course for majors. CBE Life Sci Educ 10, 113-122.

Tanner KD (2013). Structure matters: twenty-one teaching strategies to promote student engagement and cultivate classroom equity. CBE Life Sci Educ 12, 322-331

Terenzini PT, Springer L, Yaeger PM, Pascarella ET, Nora A (1996). First-generation college students: characteristics, experiences, and cognitive development. Res High Educ 37, 1-22.

Thomas CE, Richmond VP, McCroskey C (1994). The association between immediacy and socio-communicative style. Commun Res Rep 11, 107114.

Thweatt KS (1999). The impact of teacher immediacy, teacher affinity-seeking, and teacher misbehaviors on student-perceived teacher credibility. Paper presented at the National Communication Association, held November 1999 in Chicago, IL.

Tinto $\vee(1975)$. Dropout from higher education: a theoretical synthesis of recent research. Rev Educ Res 45, 89-125.

Tinto V (1997). Classrooms as communities: exploring the educational character of student persistence. J High Educ 69, 599-623.

Titsworth BS (2001). The effects of teacher immediacy, use of organizational lecture cues, and students' note-taking on cognitive learning. Commun Educ 50, 283-297.

Wilson JH, Ryan RG, Pugh JL (2010). Professor-student rapport scale predicts student outcomes. Teach Psychol 37, 246-251.

Zakrajsek T (2007). Effective teaching when class size grows. The Observer 20. www.psychologicalscience.org/observer/effective-teaching-when -class-size-grows\#.WG2UOmczXTs (accessed 7 July 2016). 